[襄化 第 35 巻，第 9 号, p. 896 901，1961]

広葉樹溶解用硫酸塩パルプに閔する研究 (第 10 報)*

ビスコース繊維の強度に対するビスコースの

流動性の重要性について（1）

高橋昭之介，藤岡靖雄，褔日祐作（日本パルプ工莱株式会社研案所）

昭和 36 年 1 月 24 日受理

緒 霉

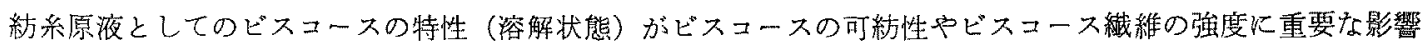

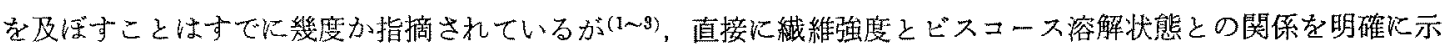
した奏験結果は従来殆えど報告されていない、ビスコースの溶解状態のマクロな不均一性はある程度ビスコース 6 濾過閉塞恒数 $\left(K_{W}\right.$ 值) から推知し得るが， $K_{W}$ 值と再生㵶維の強度との間には一定の関俰を認めることはで きず，本質的な問題は濾過された後のビスコースの性質，すなわちビスコース内での瀻維素ザンテート分子の相 互的な存在状態にむると考方られる。これはなたパプの重合度的, 微細䅉造的多分散性や化学成分純度の函数 と見なされる。

先に報告したように(4), 原料木材，蒸解法，精製法に関して種々異ったタイプのパルプを比較した場合，普通 スフ紡系条件で紡系した繊維の屈曲強度とビスコースの曳系性の間に相関が認められる。しかしその啳 L.DKP

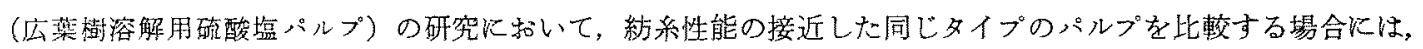

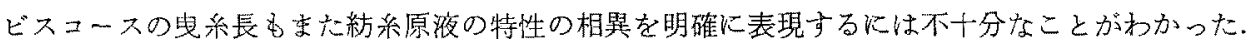

そこてビスコースに種々の剪断力を作用させた場合のビスコースの流動性の変化を追究し，ビスコース再生緎 維の強度と関連づけられるよ5なビスコース溶解状態定表す特性值について研究した結果, 若干の與味女る結果 を得たのてここに報告する。

\title{
実験方法
}

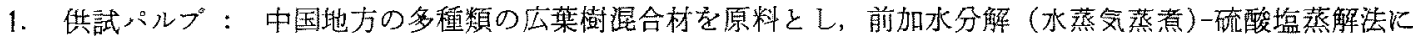

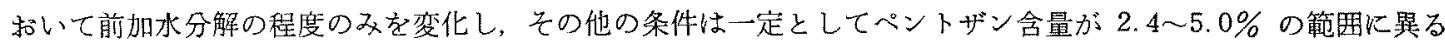
L.DKP を調製した。これらの分析值を第 1 表に示す.

2. ビスコース調製条件：[パルプ仕込量]派乾パルプ $3 \mathrm{~kg}$ ，[浸清] $216 \mathrm{~g} / 1 \mathrm{NaOH}, 20^{\circ}, 2$ 時間，[圧搾] 風乾パルプ重量に対して 2.70 倍に圧搾，[解破] Werner 型解砕機，70 分，[老成] $28^{\circ} ， 22$ 時間、[硫化] $\mathrm{CS}_{2}$

第 1 表 暗加水分解度の異る低重合度 L.DKP の裂造条件及び分析値

\begin{tabular}{|c|c|c|c|c|c|c|c|c|c|c|c|c|c|}
\hline 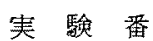 & & & & & & & & & & & & & \\
\hline it & 䦓 $(\mathrm{min})$ & 50 & 50 & 5 & 60 & 65 & 7 & 80 & & & & & \\
\hline & P.N. & 6.7 & 6 & & & 6 & & & & & & & \\
\hline & JIS 稢 度 & 10 & 10 & & & & & & & & & & \\
\hline & $\alpha-$ 繊維 & 94 & 95. & 94 & 95. & y. & 95 & 9 & Or & 9 & 96 & & 95 \\
\hline & 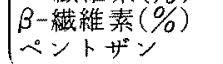 & 5 & $\begin{array}{l}\text { 2. } 2 \\
\text { 4. } 46\end{array}$ & & & 3.73 & $\begin{array}{l}2 . \\
3 .\end{array}$ & & & & & & \\
\hline & & & & & & & & & & & 3 & & \\
\hline & $a$ & 93.6 & 94.1 & 93. & 9 & 9 & 94 & 94.7 & 84 & 94 & $\pi$ & & 94. \\
\hline & $\beta$-繊維素( & 3. & 3. & 4. & 3 & 3.9 & 3. & 3. & & 4. & & & 3. \\
\hline & ペントザン $(\%$ & 5.00 & 4.16 & 4. & 4. & 3.44 & 3.6 & 3.3 & 3.05 & & & & z. \\
\hline & 脂 & - & a1 & 0.21 & 0.17 & an $\overline{1}$ & $\overline{9}$ & - & O & 0.11 & 0.07 & 0.23 & - \\
\hline & & & & & & 80.1 & & & 2. & & 89 & & \\
\hline
\end{tabular}

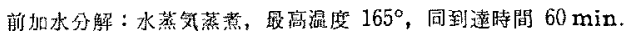

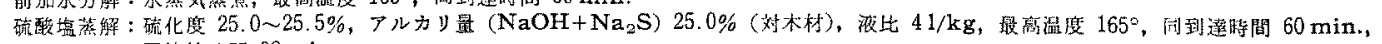
同持赎㭙間 $90 \mathrm{~min}$.

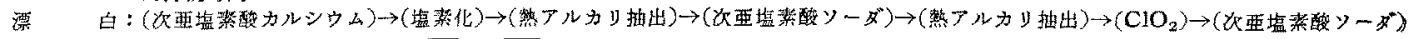

* Studies on the Hardwood Dissolving Sulphate Pulp. Part X. The Importance of Rheological Properties of Viscose on the Strength of Viscose Fibers. (1)

By Shonosuke TAKAHASHI, Yasuo FUJIOKA and Yusaku FUKUdA (Research Institute of Nippon:

Pulp Industry Co., Ltd.) 
添加量 $35 \%$ (対㵶維菜)， $25^{\circ} ， 3$ 時間，〔溶解〕䋐維素 $8 \%, \mathrm{NaOH} 6 \%, 10 \sim 20^{\circ}, 3$ 時間，〔熟成〕 $20^{\circ}$ 以下， 〔濾過】 $2 \mathrm{~kg} / \mathrm{cm}^{2}$, 金巾 2 枚, 片ネル 2 枚，〔脱泡〕50 100 $\mathrm{mmHg}$ ，約 5 時間.

3. 紡系条件（普通スフ用）：〔ノズル] $0.07 \mathrm{~mm} \phi, 2000$ holes, [ビスコース吐出速度] $185 \sim 190 \mathrm{~g} / \mathrm{min}$, [第 1 浴] $\mathrm{H}_{2} \mathrm{SO}_{4} 120 \mathrm{~g} / 1, \mathrm{Na}_{2} \mathrm{SO}_{4} 320 \mathrm{~g} / 1, \mathrm{ZnSO}_{4} 15 \mathrm{~g} / 1,46 \sim 48^{\circ}$, 浴中距離 $40 \mathrm{~cm}$, [第 2 浴] 熱水, $90^{\circ}$ 以上,

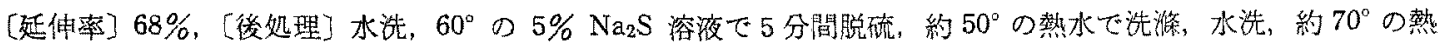
風乾燥機で乾燥.

4. ビスコースの电禾性測定及び繊維強度測定条件は既報 (4)に記載した方法に準したた，屈曲強度測定に批げる 荷重は $750 \mathrm{mg}$ とした.

5.ビスコース流動性の湘定：回転粘度計（島津慜作所 Universal Rheometer, Type：UR-1）を用い，紡 系直前（瀘過脱泡後）のビスコースについて測定した.

\section{実験 結果及び考察}

この実験では L·DKP の製造条件の中前加水分解の程度のみを变化し，他の製造条件は一定としてペントザン 含量の異る一系列の L.DKP を調製し, 前水解度の変化に伴うビスュース緎維の強度と紡系原液（ビスコース） の流動性の変化を追究して両者の関連を検討することを試みた，従って最初に普通スフ強度に対する L.DKP の ベントザン含量（前水解度）の影響について述べる.

\section{L·DKP のペントザン含量とビスコース綫維強度の関係＼cjkstart紡系試験結果（第2 表）にみられるように，} 12 種の供試パルブの各強度（特に屈曲強度）にはかなりの変動があるにもかかわらず，パルブのペントザン含量 とこれら強度との間忙何らの関係も認められず，ペントザン含量 $2.4 \sim 5.0 \%$ の範囲では少くとも普通スフの 強度はベントザン含量の多少に影響されないと結論できる．しかもこれら L.DKP の各強度は比較として同一条

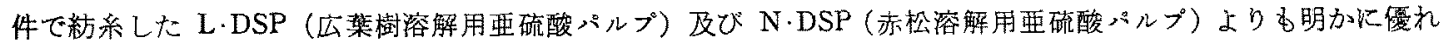
でり，ペントザン含量のかなり多い L·DKP でも高い強度のビスュース繊維を与光る DKP の特色を明瞭に示 していることは興味梁い事実である。これは第1図に示したように，たと只ルプのベントザン含量が著しく異 っていても，アルカリ浸漬，圧摧の過程でその大部分が溶出除去され，アルカリ瀻維素中に残るベントザン量と しては大差なくなること，及びこの残留ペントザンもビスュース化，紡系の過程で大半が失われると予想される ことからも予期される結果である。従来ビスュース絨維の強度に対するペントザンの悪影響が報告されている が(5,6) それらの研究は故意に数十パーセントに及ぶペントザンを混合した場合の影響を論じたものが多く，パ

\begin{tabular}{|c|c|c|c|c|c|c|c|c|c|c|c|c|c|c|}
\hline \multirow[b]{3}{*}{ ீㅜ } & \multirow[b]{3}{*}{$M \quad 70$} & \multirow{3}{*}{$\begin{array}{l}\text { 第 } 2 \text { 表 } \\
\text { ペルプ } \\
\text { ペント } \\
\text { ボン含 } \\
\text { 量 } \\
\text { (\%) }\end{array}$} & \multirow{2}{*}{\multicolumn{5}{|c|}{$\begin{array}{c}\begin{array}{c}\text { ペントザン含量の舆る低重 } \\
\text { 紡系時のビスコーース }\end{array} \\
\end{array}$}} & \multirow{3}{*}{$\begin{array}{l}\text { 繊度 } \\
(\operatorname{den})\end{array}$} & \multirow{2}{*}{\multicolumn{2}{|c|}{ 强 $/$ den $)$}} & \multirow{2}{*}{\multicolumn{2}{|c|}{$\begin{array}{c}\text { 試䍉結果 } \\
\text { 伸 度 }\end{array}$}} & \multirow{3}{*}{$\begin{array}{c}\text { 乾 湿 } \\
\text { 強度比 } \\
(\%)\end{array}$} & \multirow{3}{*}{$\begin{array}{l}\text { 属曲 } \\
\text { 強度 } \\
\text { (回) }\end{array}$} \\
\hline & & & & & & & & & & & & & & \\
\hline & & & $\begin{array}{l}\text { 落球 } \\
\text { 粘度 } \\
(\mathrm{sec})\end{array}$ & $\underset{\substack{\text { 洒 } \\
\text { H. R. }}}{ }$ & $r$-価 & $K_{W} / 10$ & $\begin{array}{l}\text { 莗系 } \\
\text { (cm) } \\
\text { (cm }\end{array}$ & & 乾 & 湿 & 乾 & 湿 & & \\
\hline \multirow{11}{*}{ 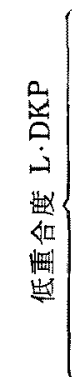 } & No. 1 & 5.00 & 42.0 & 12.5 & 40.4 & & 3.2 & 1.70 & 1 & 2. 12 & .5 & 2.0 & 68.4 & \\
\hline & No. 2 & 4. & & & & & & & & & & & & \\
\hline & No. 3 & 4.3 & 36.8 & 12.0 & & & 1 & & & & & & & \\
\hline & No & 4. & & $\begin{array}{l}12.0 \\
13.0\end{array}$ & & & 3.2 & & & & $\begin{array}{l}20.5 \\
19.9\end{array}$ & & 73. & 83 \\
\hline & $\begin{array}{l}\text { No. } \\
\text { No. }\end{array}$ & $\begin{array}{l}3 . \\
3 . \\
\text {. }\end{array}$ & 3 & 14.0 & & & & 1 . & 31 & & 21.1 & & & 10 \\
\hline & & 3. & & 11. & & & & 1. & & & 1 & & & \\
\hline & No. 8 & 3.0 & 2 & 14. & 38 & & 2 & & & & & & & \\
\hline & No. 9 & 2.9 & & & & & & 1. & 5 & & $\theta$ & & & \\
\hline & & & & 13. & 3 & & J. & 1. & & & & & & \\
\hline & $\mathrm{N}$ & 2. 49 & 30 & 12. & 40. & & 3.1 & 1. & & & & & & \\
\hline & $\begin{array}{l}\text { No. } 12 \\
\text { (AV) }\end{array}$ & 2.4 & 37. & 12.0 & - & 25.8 & - & $\begin{array}{l}1.67 \\
1.67\end{array}$ & $\begin{array}{l}3.13 \\
3.02\end{array}$ & $\begin{array}{l}\text { 2. } 10 \\
2.15\end{array}$ & $\begin{array}{l}19.9 \\
19.2\end{array}$ & $\begin{array}{l}21.6 \\
22.7\end{array}$ & 71.0 & 198 \\
\hline \multicolumn{15}{|c|}{ 輘パプ } \\
\hline & $\mathrm{N}$ & - & 40 & & - & - & - & 1. & & & & & & \\
\hline 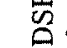 & & - & & & & & & & & & & & & \\
\hline & No & - & 39.0 & 11. & - & - & & & & & & & & 8 \\
\hline & & & & & - & & & & & & & & & \\
\hline$\frac{a}{6}$ & & - & 51 & & -7 & & - & & & & & & & \\
\hline & & - & 48.3 & 12. & - & - & 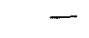 & & 2. & & 18.6 & 24 & & \\
\hline & & & & & & & & & 2. & & & 22.7 & ret & \\
\hline
\end{tabular}




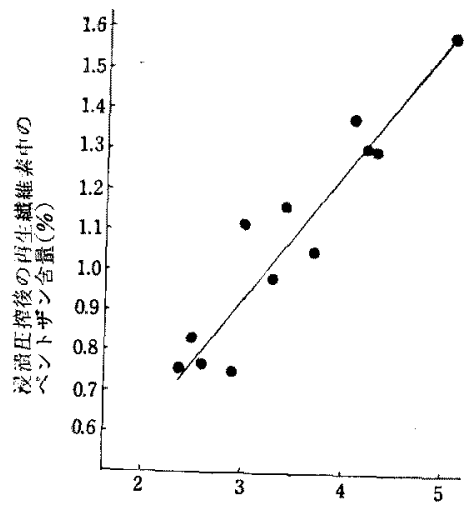

パルプのペントザン含䍜 $(\%)$

第1図低央合度 L.DKPのパルプ中の ヘンントザン含量と浸清医㩁後に再生 した緎維案中のペントザン含量之の 関倸

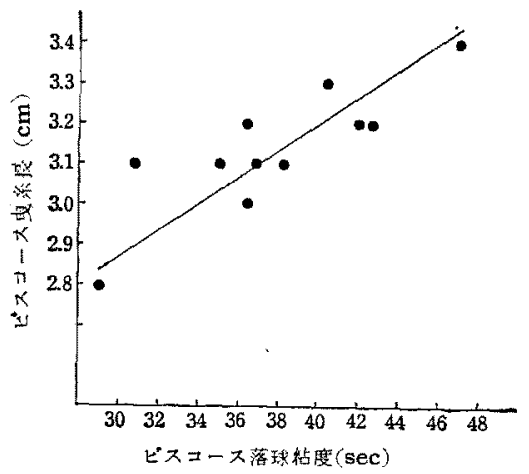

第 2 図 ペントザン含量の異る低重合度 L·DKP のビスコースの曳系長と 落球粘度の関係

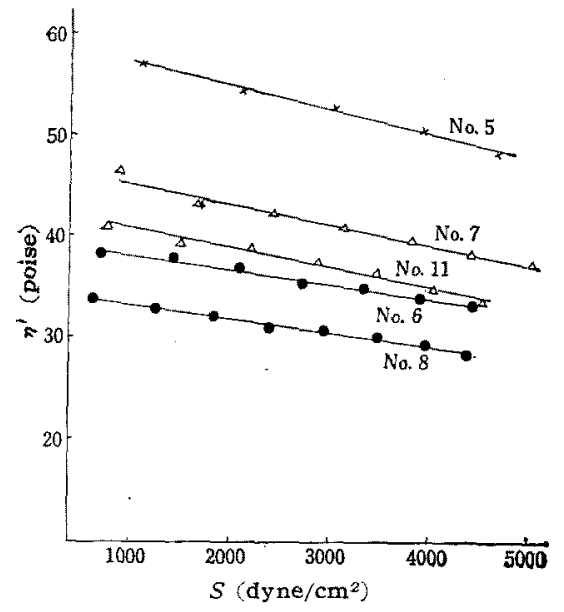

第 3 图 $\eta^{\prime}$ と剪断応力の関倸（低剪断力 範因)

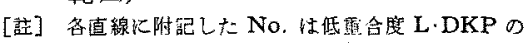

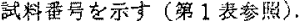

プに対して 2 3\% のペントザン含量の差が系質に影響するとは 考えられない。

広葉樹のペントザンの影響分小さいことはD．D．Bachlott(7) も 報告して和り，それよりもむしろ織維菜自体の崩壤に上って生ず る低分子物質の影響が大きいと考克られる。

2. ビスコース溶解状態の表示法について 上述の上うに第 2 表の L.DKP の晋通スフ強度の変動はパルプのペントザン含量 とは直接関連せず，従ってその他の实験条件の変動に上って生じ たものと考光ねばならないが，そのうち特に注意する必要のある のはビスコース溶解状態の変動と考えられる，しかし予期した通 りピスコースの濾過度 ( $K_{W}$ 值) はこの問題の検討には全く不十

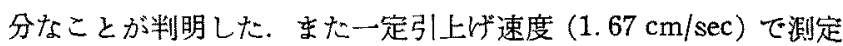
したビスコースの史系長は，これをビスュースの落球粘度に対し てプロットしてみると，大体值線関係の成立することがわかった （第 2 図)．すでに報告したよ5にビスコースの曳系長は落球粼度 の直線函数であることが確められているからら ${ }^{(4)}$ ，上述の結果は， No. 1 12 の実験例の各ビスコースの溶解状態はビスコースの电 系長で表現する限りに扎いては，殆んど同一と見做されることを 意味している。

そこでこれらのどスコースの溶解状態の美をさらに詳しく湌討 するために，回転粘度計を用いてビスコースの流動性を検討した。 測定は次の条件で行なった。

[低煎断力範囲の測定]外筒: 半经 $R_{c}=2.0 \mathrm{~cm}$, 浸液長 $L$ $=5.0 \mathrm{~cm}$. 内筒 : 半径 $R_{b}=1.35 \mathrm{~cm}$. ワイヤー：ワイヤ一常数 $=$ 4470 dyne $\mathrm{cm} /$ 偏角 $\left(^{\circ}\right)$. 外简回転速度 : $50 \sim 400 \mathrm{r}, \mathrm{p} . \mathrm{m}$.. 温孯: $20^{\circ}, 25^{\circ}$ 及び $30^{\circ}$.

[高断力範囲の測定] 外筒: 同上. 内筒 : $R_{b}=1.90 \mathrm{~cm}$. ワイヤー：ワイヤー常数 $=31600 \mathrm{dyne} \mathrm{cm} /$ 偏角 $\left({ }^{\circ}\right)$. 外筒回転速 度 : 同上. 温度 : $25^{\circ}$.

測定結果から次式によって回転粘度計化括けるコンシステンシ 一変数 (内筒表面に拈ける剪断応力 $S$ 及び新断速度 $D$ ) を求めた。

$$
S=T / 2 \pi R_{b}^{2} L
$$

$$
T=\text { (偏角) } \times(\text { ワヤー常数 })
$$$$
D=2 \Omega / 1-\left(R_{b} / R_{C}\right)^{2}
$$

$\Omega:$ 外筒の角速度 (rad./sec)

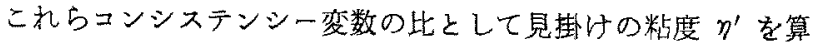
出した.

$$
\eta^{\prime}=S / D
$$

煎断広力 $S$ に対して見掛け粘度 $\eta^{\prime}$ をプロットをると第3 图及 び第 4 図に数例を示したよ この直線関係はさらに高い剪断力範围まで適用されるとは考えら れず，現実に第4図に見られるように剪断力の高い範同で若テの 偏倚が認められるが，実験範圈内でこの関係を利用してビスコー スの構造粘性の指標値を求めることは差支えないと考之られる。

上記の直線関係から次の実験式が成立する。 


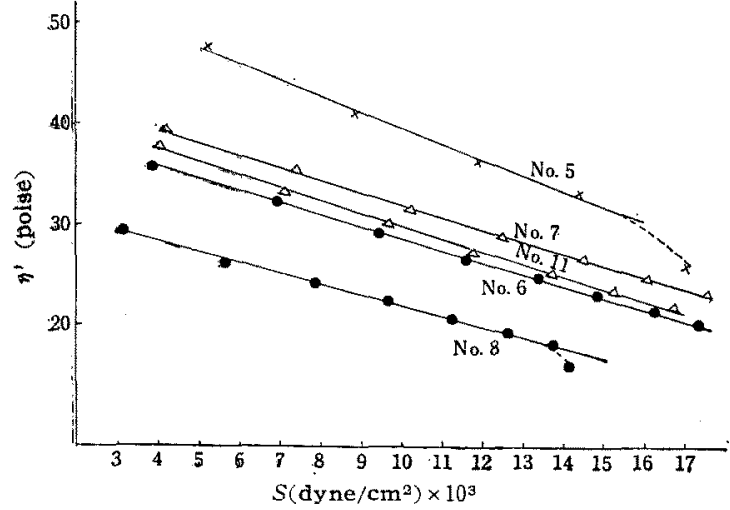

第 4 图 $\eta^{\prime}$ と剪断応力の関係 (高剪断力籍围)

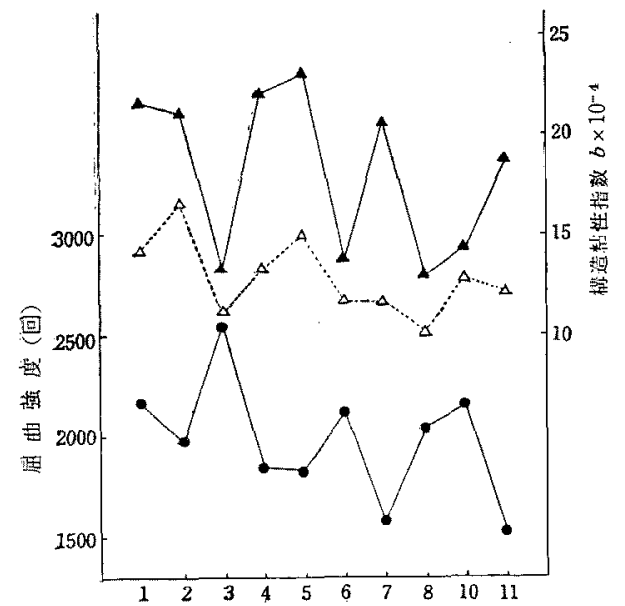

低央合度 L.DKP，パルブ武料留号 (No.)

第 5 図屈曲強度とビスコース構造粘性指数との 關係

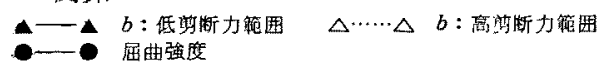

$$
\eta^{\prime}=S \mid D=a-b S
$$$$
a, b: \text { 常数 }>0
$$

Newton 液体に怙いては粘度は煎断広力に関保なく 一定であるから，

$$
\eta=a \quad \text { (常数) }
$$

が成立する妒ずで方り，従って式（4）の係数bは

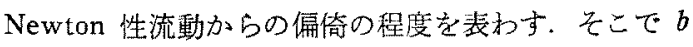
を楧造粘性指数として採用し，図式的にこの值を算出 した，その結果次項に述べるようにbの值がビスコー ス絨碓強度と関係づけれることが判明した。

3. 構造粘性指数に関する考察 前述のよ5にし て求めた構造粘性指数 $b$ を再生䋐維の屈曲強度と比較 してみると，第 5 図に示すように低剪断力範团で測定 した構造粘性指数 $b$ と罢曲強度との間に有意な真相䦭 が認められた。ところが高剪断力範困で测定した $b$ と 屈曲強度の関係はこれに較べて不明暸ですった。この 理由は次のよ5に考察される。

高分子溶液の流動曲線の形状に試料高分子物質の多 分散性が䫏われることは最近Umstätter, Edelmann (12

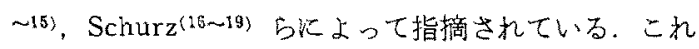
は高分子溶液の現わ寸棈造粘性が溶解精子の大きさ, 形，存在状態の統計的な分布によって支配されるため である、静止した高分子溶液内では種々の長さの分子 鎖が種々の程度に糸正化した状態で存在している。 の上5な溶液は，極めて低い煎断力範田では近似的に Newton 流動を示し, い方ゆる静粘度 $\eta_{0}$ が測定され

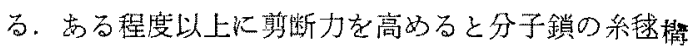
造が扡緩し，変形し，流動万向に配向する。この㙓断 力範围て Newton 流動から偏倚した異常流動が現われ る.さら剪断力を゙高めれば分子鎖のそれ以上の変形、

配向が不可能となって再び近似的に Newton 流動となり，一定の終粘度 $\eta_{\infty}$ が測定される(15). 長い分子鎖は短 い分子鎖上りも低い剪断力で変形が始まるので，大きい分子ほど小さい尊断速度で構造粘性を現わし，分子が小

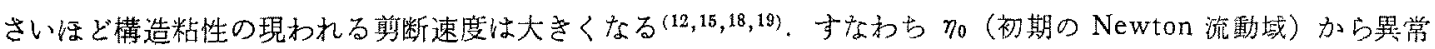
粘性域倸行する剪断速度 $D$ の值には最も大きい分子を対応させ，また異常粘性域から $\eta_{\infty}$ の领域への移行点 には構造粘性を現わし得万最も小さい分子を対応させることができる. Schurz(19) は $\log S$ に対して $\log D$ を

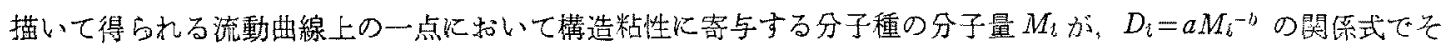

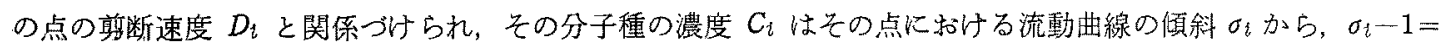
$\beta \cdot C_{1}$ の関係によって求められることを見出した.

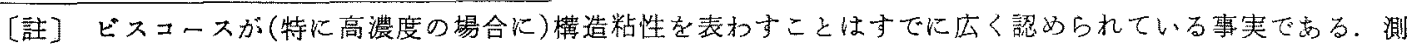
定装贯としては主に高王毛細管型粘度計が用いられ，例之ば㻕尾。稻垣氏等 ${ }^{(8)}$ は $\log \eta$ と $\log D$ の間炕直線関倸

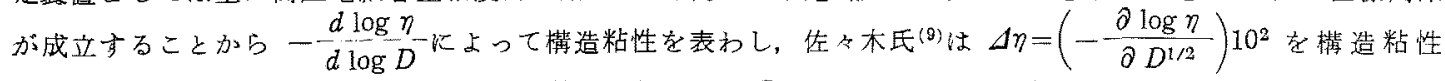

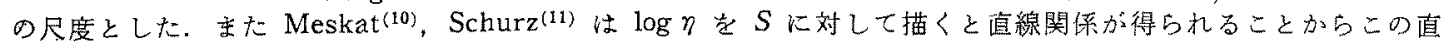
線の傾斜 $\Delta \eta$ で構造粘性を表わした $\left(\eta=\eta_{0} e^{-\Delta^{\eta} S}\right)$. これらの構造粘性指数はいずれる流動曲線を線型化するこ とによって導かれたものであるが，Schurz(11) も指摘している通りこれらの直線関係妨るる一定の㷙断条件の簌 囲内でのみ成立するむのと考元られる。本報のよ5に回転粘度計を用いた例は報告が少い上うであるが，比較的 簡単な形式で構造粘性指数を実礐的に定義できることは與味があると考える。 


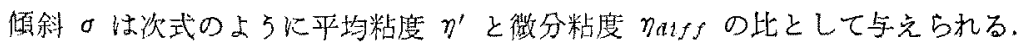

$$
\begin{gathered}
\sigma=\frac{d \log D}{d \log S}=\frac{S}{D} \cdot \frac{d D}{d S}=\frac{\eta^{\prime}}{\eta_{a t f f}} \\
\eta_{a i f f}=\frac{d S}{d D}
\end{gathered}
$$

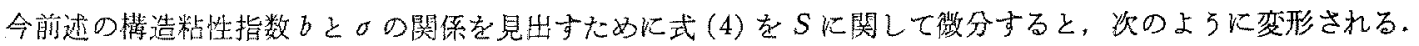

$$
1+b D=\frac{S}{D} \frac{d D}{d S}
$$

式 (6) 及び (7) より䊔造粘性指数 $b$ は次のよ 5 Kの-1と関係つけられる。

$$
\sigma-1=b D
$$

Schurz は流動曲線上の各点の $D_{i}$ とそれに対応する $0-1$ とから前記の関係を用いて重合度分布を推定した が，同様の考方方を適用すれば構造粘性指数 $b$ から重合度分布の一端を推定し得るはずである。本実験に括け る2 種の測定箸目はいずれも流動曲線 ( $\log D \sim \log S$ ) の変曲点（变曲点での剪断速度 $\hat{D}$ は平均重合度に対応）

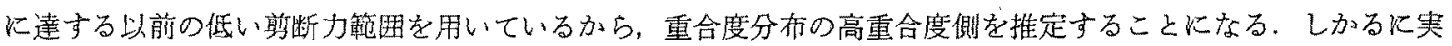
際には織維素濃度の高いビスコ一スでは完全に分子状に分散しているとは考え難く(18,20)，分子集合体(21) 或いは 未分散部分 ${ }^{22,29)}$ を含むと考兄られるので, むしるこれらをる含めて溶解粒子の大きさの分布と関連つけた方が

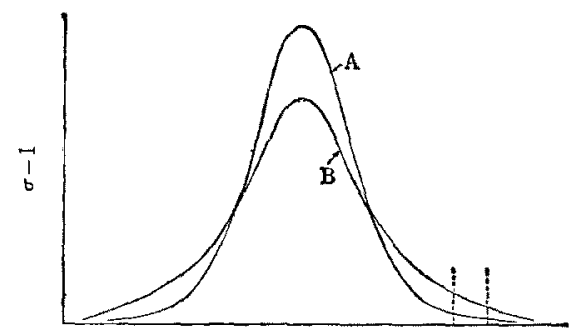

$\leftarrow D$

溶解糡于の大きさ $\rightarrow$

第 6 図蹸造粘性指数 $b$ と溶解粒子の大 きさ分布の閔係(模型図)

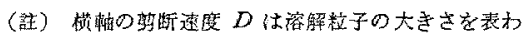
し、曲線の高さ $\sigma-1$ はそれぞれの大きさの粒子

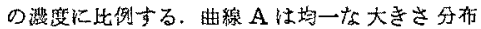

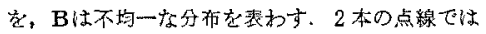

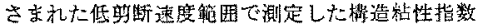

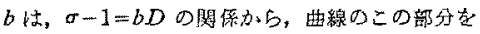

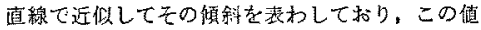
が大きいはど大塑の粒于の存在量が多いと解积で きる。

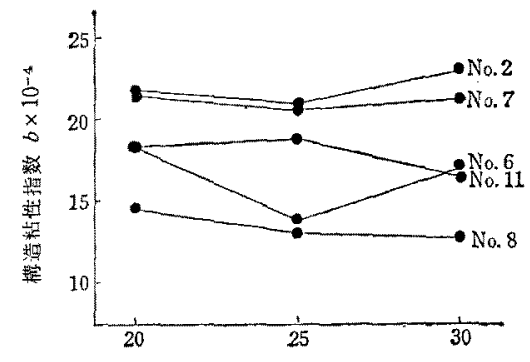

测定温度 $\left({ }^{\circ} \mathrm{C}\right)$

第 7 図 構造粘性指数 $b$ と测定温度 o睤

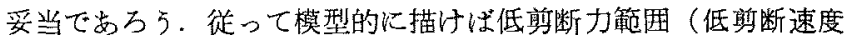
範国）で求め大構造粘性指数 bは，第 6 図に㕲ける溶解粒子分布 曲線の高粒子側の曲線の一部分を直線で近似し，その傾斜を表わ したものと考光得る。

構造粘性指数 $b$ の物理的意味を上のように考觉ると，低剪断力 範国で求めたるの值と愿曲強度とが相関することは，長い分子鎖 または大きい分子集合体が多く混在する上5などスコースの溶解 状態は糸強度に悪影響を及ぼすという事寒を示している。他方比 較的高い劕断力範国で求めた $b$ が明瞭な傾向を示さないのは，特 別偟大い分子（または集合体）以外は少くと亚通スフ紡系条 件では紡糸結果に年れはど大きい影響を及活さないことを示して いる。

系強度に晸影罄を及ぽすような大型粒子（分子又は集合体）の 生成する原因としては，パルプ中の高重合度部分の存在及びビス ニース化反応の不均一の 2 つ面が考党られる．ピスコース化反

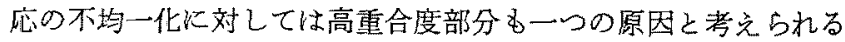

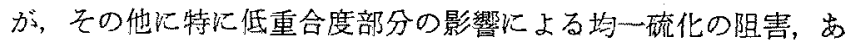
るいはビスコース化条件自体の変動も原因となると考兑られる。 本実験に関しては，L·DKP の前加水分解度と棈造粘性指数とは 一定の偭向を示さないから，前加水分解度はかなり広い範囲にわ たってビスコースの溶解状態に影響しないことが結論され，溶解 状態の変動はむしろ若千の蒸解条件の変動によって高重合度部分 が残留したためか，省いいビスコ一ス調製条件の変動によって 反応不均一を生じたたると思和れる。

な和第 7 四には構造粘性指数bと測定温度との関係を示した。 多少の变動はあるが多くの場合bは温度によって变化しないと若 党得る、従って異った温度で測定したるを此較することができる。

回轱粘度計を用いて低剪断力範团 $\left(700 \sim 5,000 \mathrm{dyne} / \mathrm{cm}^{2}\right)$ 及び比較的亮い煎断力籍囲 $(3,000 \sim 18,000$ 


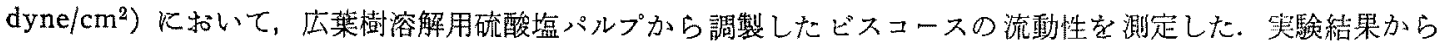

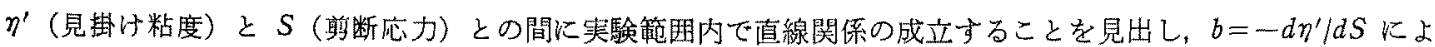

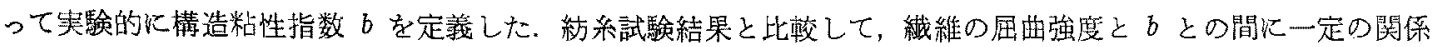
のめることが邫められた，䩑造粘性指数 $b$ の物理的意味について考察した結果，bの測定によってビスコースの

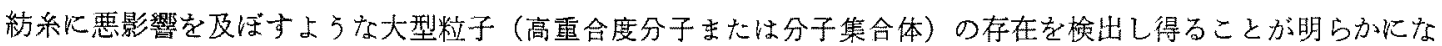
った.

終に本研究の発表を許可された当社幹部の力々に深謝申し上げ学す。

（1）煀尾正堆, 福田侑作：ハ絓工誌，6，392 (1952).

(2)近藤浩康, 佐々木俊崔：第 23 回ビスコース

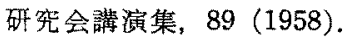

（3）向山定孝，越英夫，小管一郎：第 20 回ビス コース研究会講演集, 129 (1955).

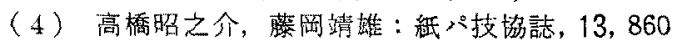
(1959).

（5）繁島滋夫，大黑田誠，今村力造：第 25 回ど スコース研究会講演(1960).

（6）䉥島滋夫, 大黑田誠，今村力造：日本化学会 第 13 年会講演 $(1960)$.

( 7 ) D. D. Bachlott, I. K. Miller, W.D. White : Tappi, 38, 503 (1955).

（8）堀尾正雄: 最新の化学々応用，第 7 策， 64 (1955)

（9）佐々木俊蜼：第 21 回ビスヌース研觉会講演 集, 79 (1956).

(10) W. Meskat: Chem. Ing. Techn., 24, 333
(1952).

(11) J. Schurz: Kolloid Z., 148, 76 (1956).

(12) K. Edelmann: Faserforsch. u. Textiltech., 5, 325 (1954).

(13) K. Edelmann : ibid., 6, 269 (1955).

(14) K. Edelmann: Kolloid Z., 145, 92 (1956).

(15) K. Edelmann: Faserforsch. u. Textiltech., 8, 184 (1957).

(16) J. Schurz: ibid., 148, 76 (1956).

(17) J. Schurz: ibid., 154, 97 (1957).

(18) J. Schurz: ibid., 155, 45 (1957).

(19) J.Schurz: ibid., 155, 55 (1957).

(20) J.Schurz: Das Papier, 12, 210 (1958).

(21) J. Manley, A. Bengtsson : Svensk Papperstidn., 61, 471 (1958).

(22) H. Dolmetsch : Melliand Textilber, 36, 766 (1955)

(23) H. Dolmetsch : Kolloid Z., 145, 141 (1956).

[賑化 第 35 巻, 第 9 号, p. 901 904, 1961]

広葉樹溶解用硫酸塩パルプに関する研究 (第 11 報)*

ビスコース緘維の強度に対するビスコースの

流動性の重要性について(2)

高橋昭之介, 藤岡靖雄, 福田鿆作 (日本ハルハプ業株式会社研究所)

昭和 36 年 1 月 24 日受理

粕言

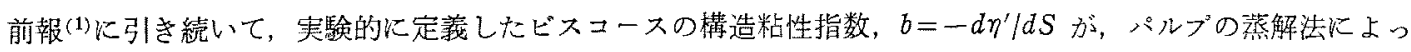

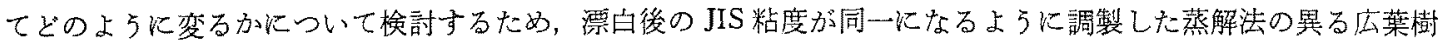
溶解用パルプからのどスコースの流動性を測定したまをた前報で性普通スフを紡系するときの構造粘性の影響を 考察したが，続いて強力スフを紡系する場合の影響を検討した．これらの結果について報告する。

\section{実験方法}

1. 蒸解法の異るパルプの比較 蒸解法としては水蒸気前加水分解一硫酸塩法, 重亚硫酸塩前蒸解一硫酸塩

* Studies on the Hardwood Dissolving Sulphate Pulp. Part XI.

The Importance of Rheological Properties of Viscose on the Strength of Viscose Fibers. (2)

By Shonosuke TAKAHASHI, Yasuo FUjIoka and Yusaku FUKUdA (Research Institute of Nippon

Pulp Industry Co., Ltd.) 